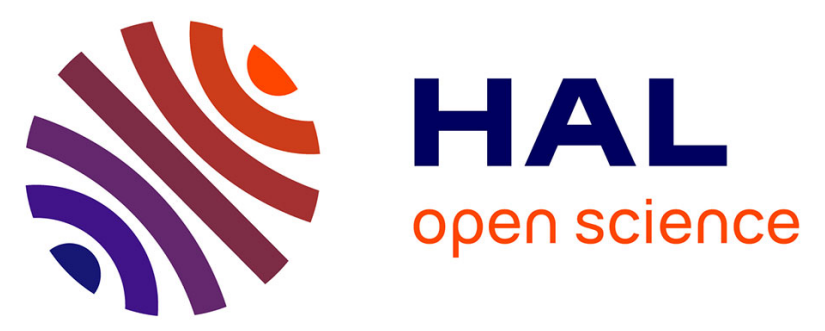

\title{
Psychosocial Impact of dysarthria: the patient-reported outcome as part of the clinical management
}

Cyril Atkinson-Clement, Alban Letanneux, Guillaume Baille, Marie-Charlotte Cuartero, Lauriane Véron-Delor, Camille Robieux, Manon Berthelot, Danièle Robert, Jean-Philippe Azulay, Luc Defebvre, et al.

\section{To cite this version:}

Cyril Atkinson-Clement, Alban Letanneux, Guillaume Baille, Marie-Charlotte Cuartero, Lauriane Véron-Delor, et al.. Psychosocial Impact of dysarthria: the patient-reported outcome as part of the clinical management. Neurodegenerative Diseases, 2019, 19 (1), pp.12-21. 10.1159/000499627 . hal02285034

\section{HAL Id: hal-02285034 https: / hal.sorbonne-universite.fr/hal-02285034}

Submitted on 12 Sep 2019

HAL is a multi-disciplinary open access archive for the deposit and dissemination of scientific research documents, whether they are published or not. The documents may come from teaching and research institutions in France or abroad, or from public or private research centers.
L'archive ouverte pluridisciplinaire HAL, est destinée au dépôt et à la diffusion de documents scientifiques de niveau recherche, publiés ou non, émanant des établissements d'enseignement et de recherche français ou étrangers, des laboratoires publics ou privés. 


\section{Psychosocial Impact of dysarthria: the patient-reported outcome as part of the clinical management}

Cyril Atkinson-Clement, $\mathrm{PhD}^{1}$, Alban Letanneux, $\mathrm{PhD}^{2}$, Guillaume Baille, $\mathrm{MD}^{3}$, Marie-Charlotte Cuartero, $\mathrm{MSc}^{4}$, Lauriane Véron-Delor, $\mathrm{MSc}^{4,5}$, Camille Robieux, $\mathrm{PhD}^{4}$, Manon Berthelot, $\mathrm{MSc}^{4}$, Danièle Robert, $\mathrm{MD}$, $\mathrm{PhD}^{4,6}$, Jean-Philippe Azulay, $\mathrm{MD}, \mathrm{PhD}^{7,8}$, Luc Defebvre, $\mathrm{MD}$, $\mathrm{PhD}^{3}$, Joaquim Ferreira, $\mathrm{MD}, \mathrm{PhD}^{9}$, Alexandre Eusebio, $\mathrm{MD}, \mathrm{PhD}^{7,8}$, Caroline Moreau, $\mathrm{MD}, \mathrm{PhD}^{3}$, Serge Pinto, $\mathrm{PhD}^{4}$

${ }^{1}$ Brain and Spine Institute (ICM), Team Movement Investigation and Therapeutics, Paris, France

${ }^{2}$ University of East-Paris-Est, Créteil, CHArt (EA 4004), UPEC-ESPE, Bonneuil-sur-Marne, France

${ }^{3}$ Department of Neurology and Movement Disorders, CHU, Lille, France, INSERM UMR_S 1171, Lille, France, University of Lille, Lille, France

${ }^{4}$ Aix Marseille Univ, CNRS, LPL, Aix-en-Provence, France

${ }^{5}$ Aix Marseille Univ, CNRS, LNC, Marseille, France

${ }^{6}$ Aix-Marseille Univ, Hôpital de la Conception, ENT Department, Assistance Publique-Hôpitaux de Marseille, France

${ }^{7}$ Aix Marseille Univ, CNRS, INT, Inst Neurosci Timone, Marseille, France

${ }^{8}$ Aix Marseille Univ, APHM, CHU Timone, Department of Neurology and Movement Disorders, Marseille, France

${ }^{9}$ Campus Neurológico Sénior (CNS), Torres Vedras, Portugal

Short Title: Psychosocial impact of dysarthria

${ }^{*}$ Corresponding Author

Cyril Atkinson-Clement, Ph.D.

Brain and Spine Institute (ICM)

Team Movement Investigation and Therapeutics

Hôpital Pitié-Salpêtrière

47 boulevard de l'Hôpital

75013, Paris, France

Tel: +33 (0)1 57274355

E-mail: c.atkinson-clement@icm-institute.org

Keywords: Dysarthria; Psychosocial impact; Voice; Speech; Self-assessment 


\section{Abstract}

Background: Dysarthria in neurological disorders can have psychosocial consequences. The dysarthic speaker's perspective towards the disorder's psychosocial impact is essential in its global assessment and management. For such purposes, assessment tools such as the Dysarthria Impact Profile (DIP) are indispensable.

Objective: We aimed to confirm the relevance of using the DIP to quantify the psychosocial consequences of dysarthria in neurological diseases.

Methods: We studied 120 participants, 15 healthy controls and 105 patients with different kinds of dysarthria induced by several neurological disorders (Parkinson's disease [PD]; Huntington's disease; dystonia; cerebellar ataxia; progressive supranuclear palsy [PSP]; multiple system atrophy; lateral amyotrophic sclerosis). All participants underwent a cognitive evaluation, a speech intelligibility assessment, and completed three self-reported questionnaires: the 36-item short form health survey, the Voice Handicap Index (VHI), and the DIP.

Results: The psychometric properties of the DIP were confirmed, including internal consistency $(\alpha=.93)$, concurrent validity (correlation with the VHI: $r=-.77)$ and discriminant validity (accuracy=.93). Psychosocial impact of dysarthria was revealed by the DIP for all patients. Intelligibility loss was found strongly correlated with the psychosocial impact of dysarthria: for a similar level of intelligibility impairment, the DIP total score was similar regardless of the pathological group. However, our findings suggest that the psychosocial impact measured by the DIP could be partially independent from the severity of dysarthria (indirectly addressed here via speech intelligibility): the DIP was able to detect patients without any intelligibility impairment, but with a psychosocial impact.

Conclusions: All patients reported a communication complaint, attested by the DIP scores, despite the fact that not all patients, notably PD, ataxic and PSP patients, had an intelligibility deficit. The DIP should be used in clinical practice to contribute to a holistic evaluation and management of functional communication in patients with dysarthria. 


\section{Introduction}

Dysarthria is common in neurological movement disorders and represents $53 \%$ of acquired communication impairments[1]. Six kinds of dysarthria were initially described by Darley et al.[2] (Fig.1). Hypokinetic and hyperkinetic dysarthrias result from subcortical dysfunctions respectively associated to reduced and increased movements; ataxic dysarthria is associated with cerebellar dysfunctions. Bilateral upper motoneuron alterations can induce spastic dysarthria, while the dysfunction of the final motor pathway can lead to flaccid dysarthria. A mixed dysarthria results from multiple brain alterations. Duffy[1] introduced two additional dysarthria types resulting from a unilateral upper motor deficit and from undetermined etiology. Dysarthria is generally assessed from a pathophysiological perspective, in that a specific disease is viewed to be the cause of a particular speech impairment. During a routine consultation, neurologists frequently rely on rating speech intelligibility, and if required, further clinical assessments and acoustic analyses can provide additional information, such as objective measures on laryngeal and supra-laryngeal articulations.

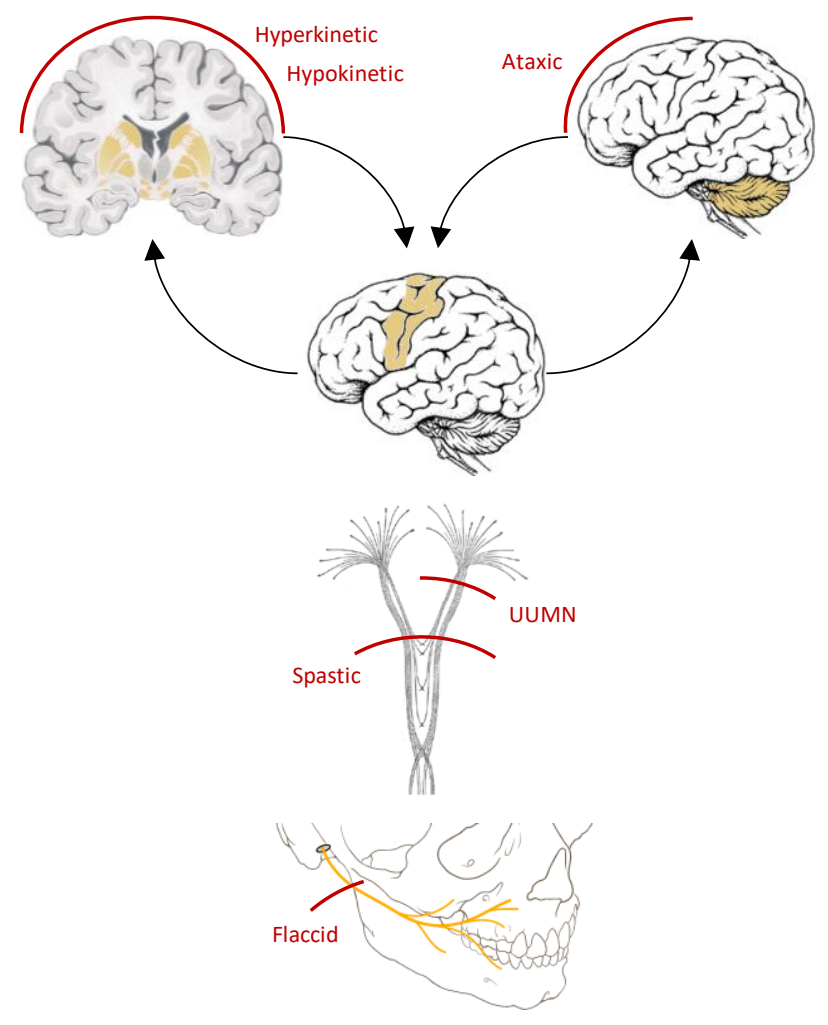

Fig.1. The different types of dysarthria according to the location of pathophysiological dysfunctions (based on previous dysarthrias classification).

Hypokinetic and hyperkinetic dysarthrias are associated to basal ganglia dysfunctions, while ataxic dysarthria results from cerebellar dysfunction. Unilateral Upper Motor Neuron (UUMN), spastic and flaccid dysarthrias are the sequel of pyramidal tract dysfunctions (upper motor neuron and unilateral for UUMN, upper motor neuron and bilateral for spastic dysarthria, and lower motor neuron for flaccid dysarthria). Not mentioned in this representation: mixed dysarthrias (resulting from multiple subcortical/cortical lesions) and dysarthria of undetermined etiology. 
Dysarthria leads to communication deficits, which frequently induce social isolation[3], a decrease in quality of life[4], and alterations in daily-living activities[5]. Such deficits also increase the risk of developing psycho-emotional disorders such as depression[6], or even cognitive deterioration[7]. Yet, the majority of assessments dedicated to speech/voice impairments are based on the symptoms themselves[8,9], and not on the symptoms' consequences. A "biomedical model of illness is inadequate in understanding the full impact of communication disorders" and "psychosocial factors should be considered"[10]. This practice leaves unanswered the symptoms' effects on quality of life, despite quality of life being dependent on those consequences that affect physical, psychological and social components[11]. A method of bridging the gap between symptom consequences on quality of life is to monitor patient-reported outcomes (PROs). PROs appear as particularly important contributions to clinical practice, especially because they report functional facts that are not systematically in agreement with the degree of severity of the symptom[12]. As stated by the PRO Harmonization Group (www.eriqa-project.com), PROs allow clinicians: 1) to better acquaint themselves with symptom consequences; 2 ) to assess the relevance of a treatment; 3 ) to guide medical choices; 4) and to improve the interpretation of clinical outcomes[13].

Among the assessments of PROs is the Dysarthria Impact Profile (DIP), which was developed and validated in English, with patients presenting with different kinds of dysarthria[14]. Its adaptations in French[15] and European Portuguese[16] have been performed, but only for hypokinetic dysarthria in PD patients. We propose here a revised French version for which all previously acknowledged limitations[15] were overcome. The objectives of the present study were to confirm the psychometric properties of this revised version of the French DIP with patients presenting with different kinds of dysarthria, and to further demonstrate the relevance of using psychosocial indicators as part of the global assessment and management of dysarthria.

\section{Materials and Methods}

\subsection{Participants}

We recruited 105 patients pertaining to seven pathological groups (15 per group) and associated with five kinds of dysarthria, including: hypokinetic (Parkinson's disease [PD]), hyperkinetic (Huntington disease [HD]; dystonia), ataxic (degenerative cerebellar ataxia) and mixed (progressive supranuclear palsy [PSP]; multiple system atrophy [MSA]; amyotrophic lateral sclerosis [ALS]). The only inclusion/exclusion criteria was that patients had had no neurostimulation, and that they were able to understand and complete the questionnaires. The patients, under usual medication, were recruited during routine outpatient visits to Neurological and ENT wards, based on neurological diagnosis and not on the presence of dysarthria. The local Ethics Committee Review Board ensured that all ethics criteria were granted in this research, which was conducted after informed consent of the patients. A group of 15 healthy controls (HC) was also recruited. Demographic and clinical characteristics of participants are summarized in Table.1. 
Table 1: Demographic data and clinical outcomes of participants.

\begin{tabular}{|c|c|c|c|c|c|c|c|c|c|c|}
\hline $\begin{array}{c}\text { Dysarthria } \\
\text { type }\end{array}$ & $\begin{array}{l}\text { Participant } \\
\text { group }\end{array}$ & $N(F / M)$ & Age (y) & $\begin{array}{l}\text { Education } \\
\text { duration (y) }\end{array}$ & $\begin{array}{c}\text { Disease } \\
\text { duration (y) }\end{array}$ & MoCA & $\begin{array}{c}\text { Intelligibility } \\
\text { (\%) }\end{array}$ & DIP & VHI & SF-36 \\
\hline & $\mathrm{HC}$ & $7 / 8$ & $61.2 \pm 6.1$ & $14.5 \pm 3.3$ & - & $28.4 \pm 1.1$ & $99 \pm 2.1$ & $204.5 \pm 18.5$ & $7.8 \pm 7.2$ & $78.9 \pm 15.3$ \\
\hline Hypokinetic & PD & $1 / 14$ & $62.7 \pm 11.4$ & $13.8 \pm 3.6$ & $7.5 \pm 4.9$ & $25.8 \pm 2.9$ & $96.7 \pm 4.5$ & $169.1 \pm 22.9$ & $31.3 \pm 22$ & $51.7 \pm 16.3$ \\
\hline \multirow{2}{*}{ Hyperkinetic } & HD & $11 / 4$ & $57.8 \pm 14.6$ & $13.1 \pm 3.6$ & $9.3 \pm 9.6$ & $20.5 \pm 5.9$ & $74 \pm 26.7$ & $152.5 \pm 26.2$ & $33.9 \pm 28.7$ & $46.4 \pm 21.5$ \\
\hline & Dystonia & $9 / 6$ & $59.7 \pm 11.3$ & $12 \pm 3$ & $16.6 \pm 12.2$ & $26.2 \pm 2.4$ & $79.3 \pm 19.5$ & $147.9 \pm 32.1$ & $63.3 \pm 27.9$ & $63.1 \pm 18.2$ \\
\hline Ataxic & Ataxia & $10 / 5$ & $52.2 \pm 14.7$ & $13.6 \pm 2.9$ & $8.5 \pm 6.4$ & $23.7 \pm 6.6$ & $91 \pm 18.9$ & $155.2 \pm 27.4$ & $38 \pm 21.5$ & $49.9 \pm 18.3$ \\
\hline \multirow{3}{*}{ Mixed } & PSP & $8 / 7$ & $72.3 \pm 8.6$ & $12.7 \pm 3.2$ & $3.6 \pm 2.9$ & $22.9 \pm 4.1$ & $83 \pm 20.1$ & $142.5 \pm 22.9$ & $49.3 \pm 29.3$ & $40.4 \pm 15.3$ \\
\hline & MSA & $2 / 13$ & $66.9 \pm 9.7$ & $11.9 \pm 4.2$ & $5.3 \pm 4.7$ & $24.6 \pm 2.1$ & $73.3 \pm 21.8$ & $140.3 \pm 24.3$ & $59.7 \pm 23.7$ & $37.7 \pm 13.3$ \\
\hline & ALS & $9 / 6$ & $70.1 \pm 10.7$ & $13.3 \pm 3.8$ & $1.7 \pm 1.5$ & $24.1 \pm 3.2$ & $48.3 \pm 34.7$ & $137.7 \pm 14.7$ & $64.3 \pm 23$ & $43.9 \pm 20.5$ \\
\hline
\end{tabular}

ALS: Amyotrophic Lateral Sclerosis; DIP: Dysarthria Impact Profile; F: Female; HC: Healthy control; HD: Huntington's disease; M: Male; MoCA: Montreal Cognitive Assessment; MSA: Multiple System Atrophy; N: number of participants; PD: Parkinson's disease; PSP: Progressive Supranuclear Palsy; SD: Standard Deviation; SF36: 36-Item Short Form Health Survey; VHI: Voice Handicap Index. For intelligibility, DIP and SF-36: the higher the score, the lower the degree of perceived handicap. For VHI: the higher the score, the higher the degree of perceived handicap. 


\subsection{Acoustic measures \& clinical assessments}

Speech intelligibility was assessed by a speech pathologist on the basis of speech records provided by the intelligibility section of the Frenchay Dysarthria Assessment (FDA-2). The participants read ten words and ten sentences, randomly and blindly chosen from a list of 116 words and 50 sentences. Intelligibility scores were reported as percentages of correctly transcribed items[17].

Among acoustic parameters, means and standard deviations of fundamental frequency (FO) and speech loudness (SPL, sound pressure level) were extracted from the sentences read by the patients. These measures were focused on in our study since monopitch and monoloudness are particular deficits often displayed in dysarthric speech.

The Montreal Cognitive Assessment (MoCA[18]) was performed to detect any cognitive impairment.

The 36-Item Short Form Health Survey (SF-36[19]) is a non-specific quality of life self-questionnaire, which examines four physical and four mental subdomains. Each subdomain is scored from 0 (maximal disturbance) to 100 (normal).

The Voice Handicap Index (VHI[8]) is often considered as the gold standard for voice self-perception[9]. It includes 30 items split into three domains: physical, functional, emotional. Each item is scored from 0 to 4: the higher the score, the higher the degree of perceived handicap.

The DIP[14-16] is composed of four numerical subscales (A: 'the effect of dysarthria on me as a speaker'; B: 'accepting my dysarthria'; C: 'how I feel others react to my speech'; D: 'how dysarthria affects my communication with others'). Each item is scored from 1 (major impact) to 5 (no impact): the lower the score, the higher the degree of psychosocial handicap. The last subscale (part E) was not included in this analysis since it is a qualitative section that does not provide any numerical score.

\subsection{Statistical analyses}

All statistical analyses were performed with R software. We calculated Cronbach's $\alpha$ to assess the internal consistency of the DIP (an adequate consistency would correspond to a coefficient of at least .70). We performed Pearson's correlations (after Holm's correction) between the scales in order to estimate the concurrent validity of the DIP, and Receiver Operating Characteristic (ROC) analyses between: 1) HC and all patients to determine discriminant validity (sensitivity, specificity, accuracy [area under the curve], power and cut-off) of the DIP, and 2) for each items of the DIP, between HC and patients to determine discriminant items and between each group of patients and the other patients to determine any specificity of each disease. Also, Hedges' g effect sizes were calculated to compare $\mathrm{HC}$ to patients. Considering the number of analyses performed, and the rather small number of participants by group, we considered as meaningful only large effect sizes ( $\mathrm{g} \geq 8$.8). Finally, we performed one linear regression to determine the influences of both intelligibility and the pathological group on the DIP total score.

\section{Results}

\subsection{Psychometric properties of the DIP}


For the total DIP score, internal consistency was confirmed for all groups ( $\alpha>.7$; Table.2.A); it was also confirmed for the four subscales when we considered all participants together: $A(\alpha=.81), B(\alpha=.71), C$ $(\alpha=0.79)$ and $D(\alpha=.85)$. The correlations we generated demonstrated that the DIP had good construct validity (Table.2.B): the total DIP score was highly correlated to the total VHI ( $r=-.77)$, SF-36 ( $r=.53$ ) and speech intelligibility ( $r=.43$ ). No correlation was found between the DIP and any acoustic measure. The highest correlations were found between the emotional part of the VHI and the subscales $\mathrm{A}, \mathrm{B}$ and $\mathrm{C}$ of the DIP (respectively, $r=-.65, r=-.62, r=-.63$ ), and between the functional part of the VHI and the subscale D of the DIP ( $r=-.78$ ). Discriminant validity was confirmed for the total DIP score (accuracy=.95; cut-off $=180 / 240$ ) and for each of the subscales: A (accuracy=.91; cut-off $=44 / 60)$, B (accuracy=.87; cutoff=38/50), C (accuracy=.87; cut-off=48/70) and D (accuracy=.96; cut-off=48/60; Table.2.C). The cutoff of the total DIP score allowed us to determine the proportion of patients who had a communication complaint: $66.6 \%$ of PD patients, $73.3 \%$ of ataxic patients, $80 \%$ of dystonic patients, $86.6 \%$ of HD patients, $93.3 \%$ of MSA patients; $100 \%$ of PSP patients and $100 \%$ of ALS patients (Fig.2). 
Table 2: Psychometric properties of the DIP: A) internal consistency (Cronbach's $\alpha$ ), B) construct validity (Pearson's correlations) and C) discriminant validity (ROC).

\begin{tabular}{|c|c|c|c|c|c|c|}
\hline & \multicolumn{5}{|c|}{ DIP } \\
\hline & & Part A & Part B & Part C & Part D & Total score \\
\hline \multicolumn{7}{|c|}{ A) Internal consistency (Cronbach's $\alpha$ ) } \\
\hline & $\mathrm{HC}$ & .72 & .70 & .83 & .70 & .90 \\
\hline Hypokinetic & PD & .79 & .60 & .77 & .71 & .91 \\
\hline \multirow{2}{*}{ Hyperkinetic } & HD & .77 & .66 & .74 & .82 & .92 \\
\hline & Dystonia & .85 & .85 & .90 & .86 & .95 \\
\hline Ataxic & Ataxia & .80 & .70 & .78 & .82 & .90 \\
\hline \multirow{3}{*}{ Mixed } & PSP & .70 & .59 & .72 & .79 & .89 \\
\hline & MSA & .79 & .52 & .66 & .79 & .89 \\
\hline & ALS & .59 & .66 & .68 & .83 & .87 \\
\hline \multicolumn{2}{|c|}{ All } & .81 & .71 & .79 & .85 & .93 \\
\hline \multicolumn{7}{|c|}{ B) Construct validity (Pearson's correlations) } \\
\hline \multirow{4}{*}{ VHI } & Part F & -.61 & -.53 & -.59 & -.78 & -.74 \\
\hline & Part P & -.58 & -.52 & -.55 & -.62 & -.66 \\
\hline & Part E & -.65 & -.62 & -.63 & -.73 & -.77 \\
\hline & Total score & -.65 & -.59 & -.62 & -.75 & -.77 \\
\hline \multicolumn{2}{|c|}{ Intelligibility } & .37 & .32 & .31 & .46 & .43 \\
\hline \multicolumn{2}{|c|}{ FO - Mean (|Z-Score |) } & .04 & .01 & .14 & .06 & .08 \\
\hline \multicolumn{2}{|c|}{ F0 - SD (|Z-Score |) } & -.07 & .03 & -.08 & -.22 & -.12 \\
\hline \multicolumn{2}{|c|}{ SPL - Mean (|Z-Score|) } & -.11 & -.11 & -.18 & -.14 & -.16 \\
\hline \multicolumn{2}{|c|}{ SPL - SD (|Z-Score |) } & -.15 & -.07 & -.04 & -.02 & -.09 \\
\hline \multicolumn{2}{|c|}{ MoCA } & .21 & .19 & .18 & .25 & .25 \\
\hline \multicolumn{2}{|c|}{ SF-36 } & .49 & .42 & .43 & .49 & .53 \\
\hline \multicolumn{7}{|c|}{ C) Discriminant validity (ROC) } \\
\hline \multicolumn{2}{|c|}{ Sensitivity } & .86 & .80 & .93 & .93 & .93 \\
\hline \multicolumn{2}{|c|}{ Specificity } & .80 & .77 & .70 & .86 & .85 \\
\hline \multicolumn{2}{|c|}{ Accuracy } & .91 & .87 & .87 & .96 & .95 \\
\hline \multicolumn{2}{|c|}{ Power } & .99 & .99 & .99 & 1 & 1 \\
\hline \multicolumn{2}{|c|}{ Cut-off } & $44 / 60$ & $38 / 50$ & $48 / 70$ & $48 / 60$ & $180 / 240$ \\
\hline
\end{tabular}

Grey values indicate that A) Cronbach' $\alpha$ was insufficient $(\alpha<.7)$ and B) correlation was not significant ( $p>$.05) after Holm's correction. ALS: Amyotrophic Lateral Sclerosis; DIP: Dysarthria Impact Profile (A: "the effect of dysarthria on me as a speaker"; B: "accepting my dysarthria"; C: "how I feel others react to my speech"; D: "how dysarthria affects my communication with others"); F: Female; F0: Fundamental frequency; HC: Healthy control; HD: Huntington's disease; M: Male; MoCA: Montreal Cognitive Assessment; MSA: Multiple System Atrophy; PD: Parkinson's disease; PSP: Progressive Supranuclear Palsy; ROC: Receiver Operating Characteristic; SD: Standard Deviation; SF-36: 36-Item Short Form Health Survey; SPL: sound pressure level; VHI: Voice Handicap Index (F: functional; P: physical; E: emotional). 

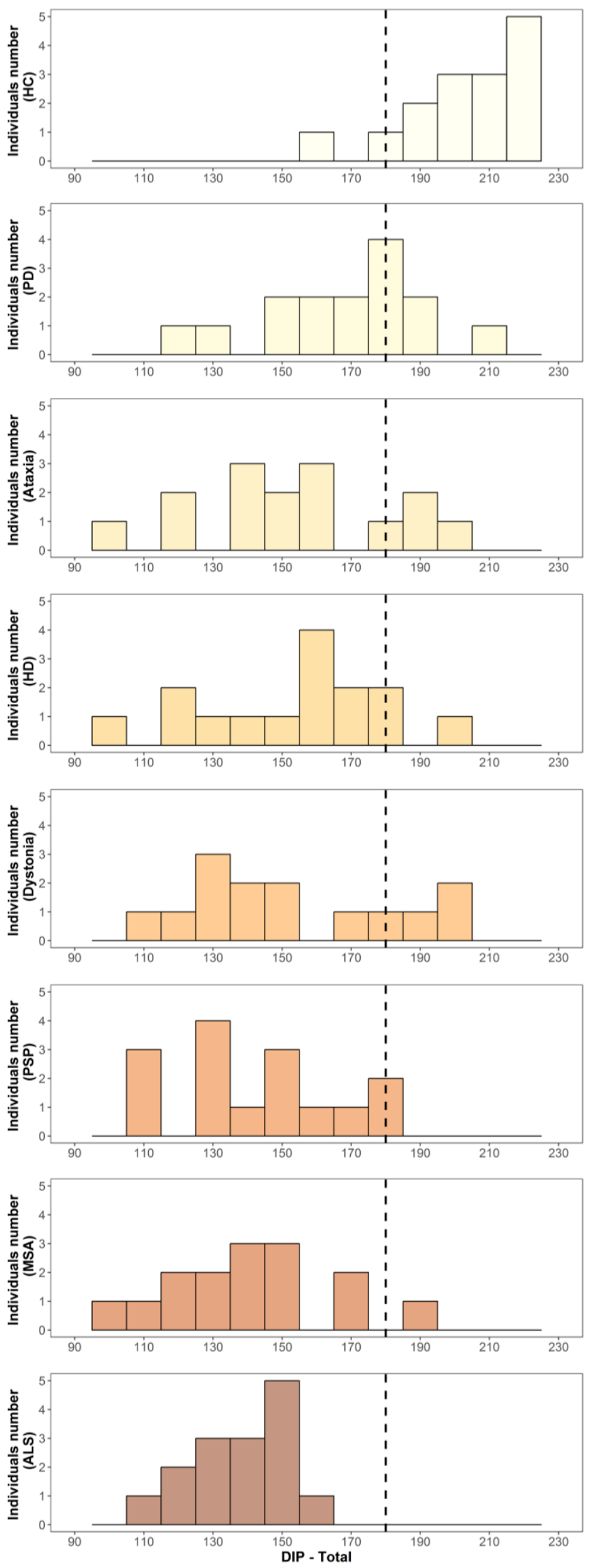
Fig.2. DIP score distributions by pathological group according to the calculated cut-off.

The vertical line represents the cut-off (180/240) for the DIP total score obtained with the ROC analysis: below 180, the DIP reveals statistically a psychosocial impact of dysarthria; above 180, the DIP score does not report an impact with functional meaning. ALS: Amyotrophic Lateral Sclerosis; DIP: Dysarthria Impact Profile; HC: Healthy control; HD: Huntington's disease; MSA: Multiple System Atrophy; PD: Parkinson's disease; PSP: Progressive Supranuclear Palsy.

\subsection{Patient phenotypes according to the communication complaint}

Patient phenotypes were ranked according to the total DIP score, from the smallest to the highest complaint: PD ( $\overline{\mathrm{x}}=169.1)$, Ataxia $(\bar{x}=155.2), \mathrm{HD}(\bar{x}=152.5)$, Dystonia $(\overline{\mathrm{x}}=147.9), \mathrm{PSP}(\bar{x}=142.5), \mathrm{MSA}$ $(\overline{\mathrm{X}}=140.3)$ and ALS $(\overline{\mathrm{X}}=137.7)$. Hedges' $\mathrm{g}$ effect sizes between patients and HC for the DIP and VHI subscales demonstrated that all patients reported a dysarthria complaint (g>.8). However, PD, ataxic and PSP patients did not show any decrease of intelligibility $(\mathrm{g}<.8)$. Most of the items were discriminant between each group of patients and the controls (Fig.3, upper part of the right panels). No items reached the threshold of accuracy between PD patients and other patients, while only one item was significant for ataxic patients ( $C 13 ; p=.008$ ) and dystonic patients (D04; $p=.027$ ). For HD, PSP and MSA patients, between 4 and 5 items were significantly discriminant from other patients (Fig.3). Lastly, for ALS patients, eleven items, ranging from A06 to D12 were significant $(p<.05)$. We also observed that both the pathological group $\left(F_{(7 ; 104)}=12.97 ; p<.001\right)$ and the intelligibility score $\left(F_{(1 ; 104)}=6.87 ; p=.01\right)$ had an effect on the total DIP score, but without any significant interaction $\left(F_{(7 ; 104)}=0.97 ; p=.45\right)$. 


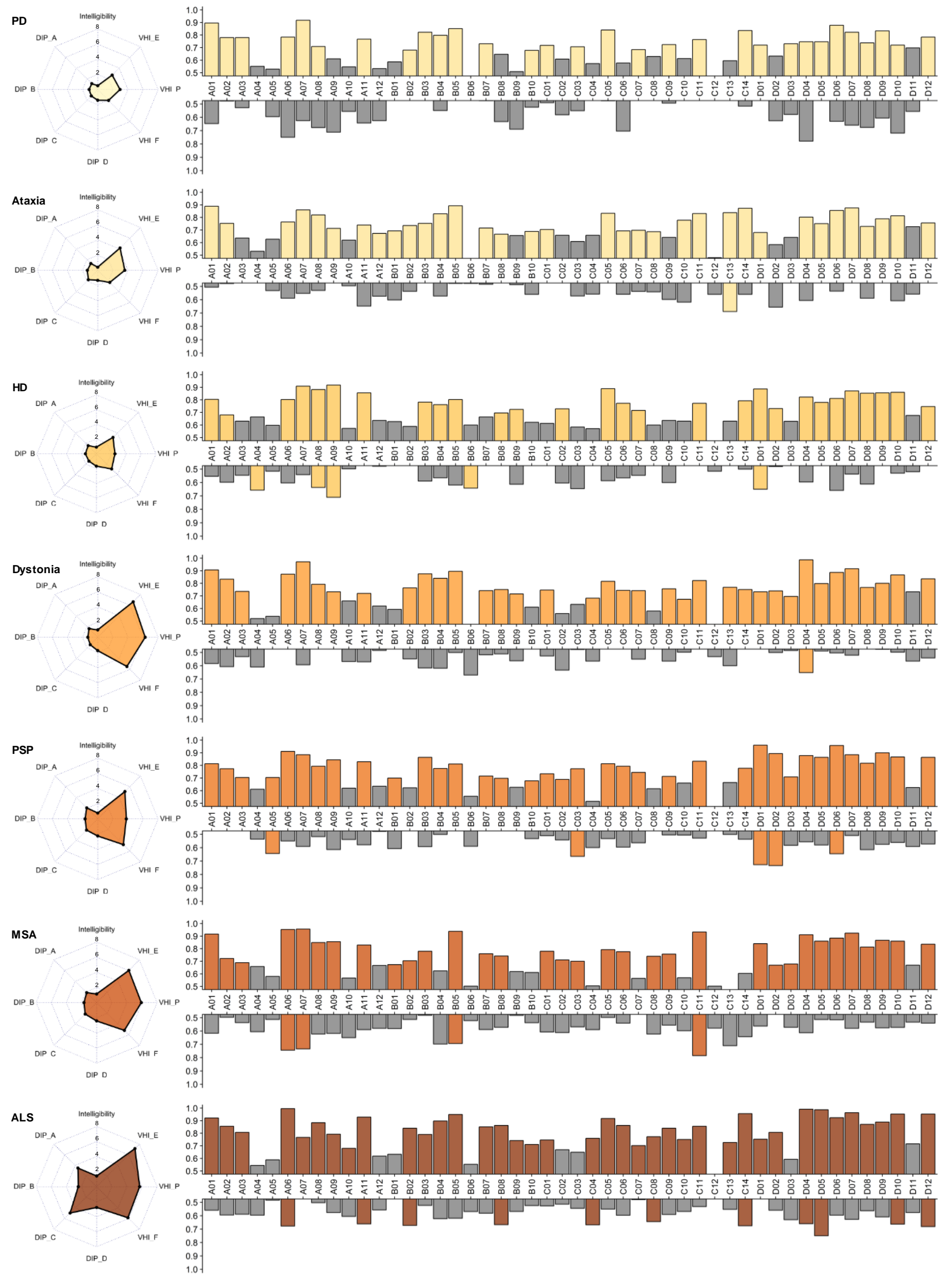


Fig.3. Dysarthria phenotypes according to the pathological groups.

Left panel: the profile diagrams are based on Hedges' $\mathrm{g}$ effect sizes between healthy controls and each group of patients. Right panel: accuracy scores for each DIP items (from A01 to D12) between the pathological group and the healthy control group (top panel), and between the pathological group and the other pathological groups (bottom panel). The colored bars correspond to meaningful items. ALS: Amyotrophic Lateral Sclerosis; DIP: Dysarthria Impact Profile (A: "the effect of dysarthria on me as a speaker"; B: "accepting my dysarthria"; C: "how I feel others react to my speech"; D: "how dysarthria affects my communication with others"); HD: Huntington's disease; MSA: Multiple System Atrophy; ns: not significant; PD: Parkinson's disease; PSP: Progressive Supranuclear Palsy; VHI: Voice Handicap Index (F: functional; P: physical; E: emotional).

\section{Discussion}

All patients reported a communication complaint, regardless of the presence of speech impairment clinically estimated via speech intelligibility. Interestingly, PD, ataxic and PSP patients did not show any deficit of speech intelligibility. Our study suggests that it would be relevant to take into account psychosocial indicators of dysarthria in patients with neurodegenerative disorders.

\subsection{Psychometric confirmation of the DIP}

Our study confirmed the psychometric properties of the revised French version of the DIP, thus validating the use of this self-questionnaire for estimating the impact of dysarthria in patients with several neurodegenerative disorders. The original DIP was administered to 31 people with different types of dysarthria[14], and consecutive adaptations in other languages confirmed its relevance for the management of PD $[15,16]$. Our results go one step beyond the use of the DIP as part of the clinical assessment of dysarthria, providing such evidence from a protocol that overcame the limitations of the previous version. Notably, we included a larger number of participants with different diseases and different kinds of dysarthria, we rephrased unclear statements and we perfected the formal presentation of the questionnaire (Supplementary material). In addition, the new formal organization of the DIP makes it easy to quickly determine whether the questionnaire has been properly completed: answering the questionnaire requires alternating between the responses "agree" and "disagree". As suggested by the absence of correlation between the DIP and the MoCA, the DIP score is either not or only weakly driven by the cognitive status of the patients. The DIP can thus be administered to patients with mild cognitive impairment, but we recommend that patients with higher cognitive impairments fill out the DIP with the help of a clinician or a caregiver.

\subsection{Speech intelligibility is not functional communication}

Our findings suggest that intelligibility loss is crucially correlated to the psychosocial impact of dysarthria. This means that, for a similar level of intelligibility impairment, the DIP total score is similar regardless of the pathological group. Nevertheless, the intelligibility score remains insufficient to address the psychosocial impact of dysarthria for at least two reasons: 1) the intelligibility score explained only $18.5 \%$ of the total DIP score (determination coefficient; $r^{2}$ ); 2 ) two patient groups (PD 
and Ataxia) displayed a significant DIP score (in comparison to the controls), but a level of speech impairment not so significant to impair intelligibility. Our findings suggest that the psychosocial impact measured by the DIP could be partially independent from the severity of dysarthria (indirectly addressed here via speech intelligibility): the DIP was able to detect patients without any intelligibility impairment, but with a psychosocial impact. This might be related to the observed independence between the perspective of the patients and those of the caregivers on communication effectiveness[20]. Thus, the assessment of speech intelligibility, which is central in the neurological investigation of dysarthria, remains insufficient to address the patient's complaints and could not represent per se the sole indicator of speech evaluation and management in clinical routine[21]. Indeed, one study showed that the majority of patients with Parkinsonian syndromes reported a communication impairment, even if some of them remained intelligible[22]. It is necessary to consider that communication ability depends on intelligibility, but also on how patients feel about the perception of others[22]. For example, based on a literature review, only $5 \%$ of scientific research in 2007 focused on psychosocial aspects of dysarthria[23]. The ROC analysis of DIP items demonstrated (especially for PD, ataxic and PSP patients who had no significant intelligibility deficit) that psychosocial consequences of dysarthria could be due to the reactions of others ("I never feel that others laugh or make fun of my speech" [C13, significant for ataxic patients]). The analysis also showed that psychosocial consequences could lower patients' self-perception ("I am as confident now as I was before I had a speech problem" [A05, significant for PSP patients]) and contribute to the isolation of patients ("Although I have difficulty speaking I do not avoid communicating with people I know" [D01, significant for PSP patients]; "My social life has not changed as a result of my dysarthria" [D02, significant for PSP patients]). Thus, our results are in agreement with a previous qualitative report that focused on acquired dysarthria and for which several themes were frequently mentioned by patients: "communication has changed", "people treat me differently", "dysarthria resulting in negative emotions", "barriers to communicate", "life is different now" [24]. So far, this statement remains topical and underlies the fact that dysarthria is a functional symptom which is still undervalued.

\subsection{Enhancing clinical assessment and management of dysarthria with the PRO}

On the exclusive basis of the neurological assessment, patients with dysarthria are generally referred to a speech therapist/pathologist only when intelligibility is significantly impaired. This might explain the gap between the number of patients with dysarthria complaints and the number of patients who have received speech therapy. For example, it has been reported that 70 to $90 \%$ of PD patients complain about speech impairment; $29 \%$ of the patients reported that dysarthria had a significant impact in their life; but only $3 \%$ accessed speech therapy[25]; though these numbers have recently improved[26]. Speech therapy can improve communication abilities and reduce social isolation[27]. Thus, patients should be seen earlier than they are currently to help reduce the psychosocial impact. Indeed, a recent study on PD reported that a longer disease duration is associated with a lower speech therapy efficacy[28]. The ROC analyses we conducted provided a cut-off of the DIP, below which the complaint of the patients should be further discussed with them and possibly, the patients could be referred to a speech/language therapist for additional counselling: clinicians could use the DIP as a tool to precisely estimate the psychosocial consequences of dysarthria[29]. Furthermore, to better manage dysarthria, it is crucial to include patient-reported difficulties in functional communication[26] as 
indicators of both dysarthria's psychosocial impact[29] and speech therapy management[27,30,31]. Thus, using the DIP as a psychosocial indicator can be useful to correctly adjusting a speech rehabilitation program[32,33].

\subsection{Limitations of the study}

Our study included some limitations. First, our patient groups included an amount of intra-group heterogeneity in terms of symptom expression, etiology, disease severity, disease duration, etc. However, our objective was to highlight the relevance of using the DIP with patients suffering from different neurodegenerative diseases, with no specific criteria of exclusion (except other neurological or psychiatric history). Second, we did not have access to information related to social environment, professional context and even cultural information. These data could be of importance to better identify complaints of communication, and have to be considered in clinical practice on a patient-bypatient individual basis. Finally, we did not evaluate depression, apathy or anhedonia, which could contribute to altering functional communication. Additional and specific studies are still required to overcome these limitations.

\section{Conclusion}

Dysarthria is a frequent and debilitating symptom of neurological disorders, and is from the patient perspective, a multidimensional symptom, impacting also social and emotional daily-living components[24]. However, the proportion of patients who access speech therapy is significantly lower than the proportion of patients who complain about communication. Integrating an additional tool such as the DIP, which provides the patient's point-of-view, is important to better identify patients with a communication complaint, especially when these patients remain intelligible. Thus, communication ought to be assessed from a holistic perspective, including both professional expertise and the patient's feelings.

\section{Statements}

\subsection{Acknowledgement}

The authors would like to thank the neurologists, the ENTs and the clinical research associates who contributed to the patient recruitment: in Lille (Nicolas Carriere, Adrian Degardin, David Devos, Alexandre Kreisler, Clémence Simonin) and in Marseille (Frédérique Fluchère, Laura Mundler, Manel Nouira, Elsa Robin, Sophie Soulayrol, Tatiana Witjas). The authors would also like to thank MarieHélène Mignard, Oriana Collins and Karl Neergaard for helpful English revisions of the article. Also, the authors wish to thank Margaret Walshe, Richard K. Peach and Nick Miller for their pioneering work on the Dysarthria Impact Profile. 


\subsection{Statement of Ethics}

Subjects have given their informed consent.

The study protocol was approved by the local research institute's committee on human research.

\subsection{Disclosure Statement}

The authors have no conflicts of interest to declare.

\subsection{Funding Sources}

This work was supported by the PACA Regional Council and Orthomalin [Ph.D grant]; and by a France/Portugal bilateral funding [ANR-13-ISH2-0001-01; FCT-ANR/NEU-SCC/0005/2013].

\subsection{Author Contributions}

1. Research Project: A. Conception, B. Organization, C. Execution;

2. Statistical Analysis: A. Design, B. Execution, C. Review and Critique;

3. Manuscript Preparation: A. Writing the First Draft, B. Review and Critique.

CAC: $1 \mathrm{~A} ; 1 \mathrm{~B} ; 1 \mathrm{C} ; 2 \mathrm{~A} ; 2 \mathrm{~B} ; 3 \mathrm{~A}$

AL: $1 \mathrm{~A} ; 1 \mathrm{~B} ; 1 \mathrm{C} ; 3 \mathrm{~B}$

GB: $1 C ; 2 C ; 3 B$

MCC: $1 C ; 2 C ; 3 B$

LVD: $1 C ; 2 C ; 3 B$

CR: 1C;3B

MB: 1A;1C;3B

DR: 1C;3B

JPA: 1C;3B

LD: $1 C ; 3 B$

$J F: 3 B$

$A E: 1 C ; 3 B$

CM: 1C;3B

SP: $1 A ; 1 B ; 2 C ; 3 A$ 


\section{References}

1 Duffy JR: Motor speech disorders: substrates, differential diagnosis, and management. 2nd ed St. Louis, Mo, Elsevier Mosby, 2005.

2 Darley FL, Aronson AE, Brown JR: Clusters of deviant speech dimensions in the dysarthrias. J Speech Hear Res 1969;12:462-496.

3 Karlsen KH, Tandberg E, Arsland D, Larsen JP: Health related quality of life in Parkinson's disease: a prospective longitudinal study. J Neurol Neurosurg Psychiatry 2000;69:584-589.

4 Kuopio AM, Marttila RJ, Helenius H, Toivonen M, Rinne UK: The quality of life in Parkinson's disease. Mov Disord 2000;15:216-223.

5 Miller N, Allcock L, Jones D, Noble E, Hildreth AJ, Burn DJ: Prevalence and pattern of perceived intelligibility changes in Parkinson's disease. J Neurol Neurosurg Psychiatry 2007;78:1188-1190.

6 Miller N, Noble E, Jones D, Allcock L, Burn DJ: How do I sound to me? Perceived changes in communication in Parkinson's disease. Clin Rehabil 2008;22:14-22.

7 Rektorova I, Mekyska J, Janousova E, Kostalova M, Eliasova I, Mrackova M, et al.: Speech prosody impairment predicts cognitive decline in Parkinson's disease. Parkinsonism Relat Disord 2016;29:90-95.

8 Jacobson BH, Johnson A, Grywalski C, Silbergleit A, Jacobson G, Benninger MS, et al.: The Voice Handicap Index (VHI): Development and Validation. Am J Speech Lang Pathol 1997;6:66-70.

9 Kasper C, Schuster M, Psychogios G, Zenk J, Ströbele A, Rosanowski F, et al.: Voice handicap index and voice-related quality of life in small laryngeal carcinoma. Eur Arch Otorhinolaryngol 2011;268:401-404.

10 Wray F, Clarke D: Longer-term needs of stroke survivors with communication difficulties living in the community: a systematic review and thematic synthesis of qualitative studies. BMJ Open 2017;7:e017944.

11 WHO | International Classification of Functioning, Disability and Health (ICF) [cited 2017 Jul 13];Available from: http://www.who.int/classifications/icf/icf_more/en/

12 Wiklund I, Comerford MB, Dimenäs E: The relationship between exercise tolerance and quality of life in angina pectoris. Clin Cardiol 1991;14:204-208.

13 Acquadro C, Berzon R, Dubois D, Leidy N, Marquis P, Revicki D, et al.: Incorporating the patient's perspective into drug development and communication: an ad hoc task force report of the Patient-Reported Outcomes (PRO) Harmonization Group meeting at the Food and Drug Administration, February 16, 2001. Value Health 2003;6:522-531. 
14 Walshe M, Peach RK, Miller N: Dysarthria impact profile: development of a scale to measure psychosocial effects. Int J Lang Commun Disord 2009;44:693-715.

15 Letanneux A, Walshe M, Viallet F, Pinto S: The Dysarthria Impact Profile: A Preliminary French Experience with Parkinson's Disease. Park Dis 2013;2013:403680:1-6.

16 Cardoso R, Guimarães I, Santos H, Loureiro R, Domingos J, Abreu D, et al.: Psychosocial impact of Parkinson's disease-associated dysarthria: Cross-cultural adaptation and validation of the Dysarthria Impact Profile into European Portuguese: EP: DIP validation for PD. Geriatr Gerontol Int 2018;18:767-774.

17 Enderby P, Palmer R: FDA-2 : Frenchay Dysarthria Assessment : Examiner's Manual. Austin, TX : Pro-Ed, 2008.

18 Nasreddine ZS, Phillips NA, Bédirian V, Charbonneau S, Whitehead V, Collin I, et al.: The Montreal Cognitive Assessment, MoCA: a brief screening tool for mild cognitive impairment. J Am Geriatr Soc 2005;53:695-699.

19 Ware JE, Sherbourne CD: The MOS 36-Item Short-Form Health Survey (SF-36): I. Conceptual Framework and Item Selection. Med Care 1992;30:473-483.

20 McAuliffe MJ, Carpenter S, Moran C: Speech intelligibility and perceptions of communication effectiveness by speakers with dysarthria following traumatic brain injury and their communication partners. Brain Inj 2010;24:1408-1415.

21 Barnish MS, Horton SMC, Butterfint ZR, Clark AB, Atkinson RA, Deane KHO: Speech and communication in Parkinson's disease: a cross-sectional exploratory study in the UK. BMJ Open 2017;7:e014642.

22 Wiblin L, Durcan R, Lee M, Brittain K: The Importance of Connection to Others in QoL in MSA and PSP. Park Dis 2017;2017:1-9.

23 Yorkston KM: The degenerative dysarthrias: a window into critical clinical and research issues. Folia Phoniatr Logop 2007;59:107-117.

24 Walshe M, Miller N: Living with acquired dysarthria: the speaker's perspective. Disabil Rehabil 2011;33:195-203.

25 Hartelius L, Svensson P: Speech and swallowing symptoms associated with Parkinson's disease and multiple sclerosis: a survey. Folia Phoniatr Logop 1994;46:9-17.

26 Schalling E, Johansson K, Hartelius L: Speech and Communication Changes Reported by People with Parkinson's Disease. Folia Phoniatr Logop 2017;69:131-141.

27 Fogg-Rogers L, Buetow S, Talmage A, McCann CM, Leão SHS, Tippett L, et al.: Choral singing therapy following stroke or Parkinson's disease: an exploration of participants' experiences. Disabil Rehabil 2016;38:952-962. 
28 Boutsen F, Park E, Dvorak J, Cid C: Prosodic Improvement in Persons with Parkinson Disease Receiving SPEAK OUT! ${ }^{\circledR}$ Voice Therapy. Folia Phoniatr Logop 2018;70:51-58.

29 Pinto S, Cardoso R, Sadat J, Guimarães I, Mercier C, Santos H, et al.: Dysarthria in individuals with Parkinson's disease: a protocol for a binational, cross-sectional, case-controlled study in French and European Portuguese (FraLusoPark). BMJ Open 2016;6:e012885.

30 Ramig L, Halpern A, Spielman J, Fox C, Freeman K: Speech treatment in Parkinson's disease: Randomized controlled trial (RCT): SPEECH TREATMENT IN PARKINSON'S DISEASE: RCT. Mov Disord 2018;33:1777-1791.

31 Mackenzie C, Lowit A: Behavioural intervention effects in dysarthria following stroke: communication effectiveness, intelligibility and dysarthria impact. Int J Lang Commun Disord 2007;42:131-153.

32 Atkinson-Clement C, Sadat J, Pinto S: Behavioral treatments for speech in Parkinson's disease: meta-analyses and review of the literature. Neurodegener Dis Manag 2015;5:233-248.

33 Enderby P: Disorders of communication; in : Handbook of Clinical Neurology. Elsevier, 2013, pp 273-281.

\section{Supplementary materiel}


A) L'EFFET DE LA DYSARTHRIE SUR MOI EN TANT QU'INDIVIDU

A.1

Mon problème de parole a eu un effet négatif sur la façon dont je me perçois

Fortement en

désaccord

En désaccord

Pas sûr(e)

En accord

Fortement en accord

Quand je parle, j'ai l'impression d'entendre quelqu'un d'autre que moi

Fortement en

désaccord

En désaccord

Pas sûr(e)

En accord

Fortement en accord

Maintenant, même quand je ne parle pas, j'ai l'impression d'être une personne différente

Fortement en

désaccord

En désaccord

Pas sûr(e)

En accord

Fortement en accord

Je n'ai pas l'impression de ne pas être à la hauteur à cause de ma parole

Fortement en désaccord

En désaccord

Pas sûr(e)

En accord

Fortement en accord

Maintenant, je suis autant sûr(e) de moi qu'avant mon problème de parole

Fortement en

désaccord

En désaccord

Pas sûr(e)

En accord

Fortement en accord

En raison de ma parole, je suis maintenant plus dépendant(e) des autres que je ne l'étais auparavant
Fortement en
Pas sûr(e)
En accord
Fortement en
désaccord
En désaccord

Pas sûr $(e)$ accord

A. 7

Je ne me sens pas embarrassé(e) par ma parole

Fortement en désaccord

En désaccord

Pas sûr(e)

En accord

Fortement en accord

Je ne me sens pas incompétent(e) à cause de ma parole

Fortement en désaccord
En désaccord

Pas sûr(e)

En accord

Fortement en accord

Je ne me sens pas idiot(e) lorsque je suis incompris(e)

\begin{tabular}{|c|c|c|c|c|}
\hline $\begin{array}{l}\text { Fortement en } \\
\text { désaccord }\end{array}$ & En désaccord & Pas sûr(e) & En accord & $\begin{array}{c}\text { Fortement en } \\
\text { accord }\end{array}$ \\
\hline
\end{tabular}

Je me sens stupide lorsqu'on me demande de répéter
Fortement en
désaccord
En désaccord
Pas sûr(e)
En accord
Fortement en accord

Maintenant, j'ai l'impression d'avoir moins de contrôle sur ma vie à cause de ma parole

Fortement en désaccord
En désaccord

Pas sûr(e)

En accord

Fortement en accord

Mon problème de parole ne m'a pas fondamentalement changé(e) en tant qu'individu

Fortement en désaccord
En désaccord

Pas sûr(e)

En accord

Fortement en accord 
B. 1

Je n'essaye pas de cacher mes difficultés de parole

$\begin{array}{clll}\begin{array}{c}\text { Fortement en } \\ \text { désaccord }\end{array} & \text { En désaccord } & \text { Pas sûr(e) En accord } & \begin{array}{c}\text { Fortement en } \\ \text { accord }\end{array}\end{array}$

B.2

Je me fâche quand les gens ne me comprennent pas

$\begin{array}{ccccc}\begin{array}{c}\text { Fortement en } \\ \text { désaccord }\end{array} & \text { En désaccord } & \text { Pas sûr(e) } & \text { En accord } & \begin{array}{c}\text { Fortement en } \\ \text { accord }\end{array}\end{array}$

B.3

(e ne ma parole en l'état actue

\begin{tabular}{|c|c|c|c|c|}
\hline $\begin{array}{l}\text { Fortement en } \\
\text { désaccord }\end{array}$ & En désaccord & Pas sûr(e) & En accord & $\begin{array}{l}\text { Fortement en } \\
\text { accord }\end{array}$ \\
\hline
\end{tabular}

B.4

Je suis susceptible concernant ma parole

\begin{tabular}{ccccc}
$\begin{array}{c}\text { Fortement en } \\
\text { désaccord }\end{array}$ & En désaccord & Pas sûr(e) & En accord & $\begin{array}{c}\text { Fortement en } \\
\text { accord }\end{array}$ \\
\hline $\begin{array}{c}\text { Fortement en } \\
\text { désaccord }\end{array}$ & En désaccord & Pas sûr(e) & En accord & $\begin{array}{c}\text { Fortement en } \\
\text { accord }\end{array}$
\end{tabular}

B.6

Cela ne me dérange pas d'admettre que j'ai un problème de parole

\begin{tabular}{|c|c|c|c|c|}
\hline $\begin{array}{c}\text { Fortement en } \\
\text { désaccord }\end{array}$ & En désaccord & Pas sûr(e) & En accord & $\begin{array}{c}\text { Fortement en } \\
\text { accord }\end{array}$ \\
\hline
\end{tabular}

B.7 Je préfère perdre le fil des conversations plutôt que d'admettre avoir un problème de parole

\begin{tabular}{|c|c|c|c|c|}
\hline $\begin{array}{l}\text { Fortement en } \\
\text { désaccord }\end{array}$ & En désaccord & Pas sûr(e) & En accord & $\begin{array}{l}\text { Fortement en } \\
\text { accord }\end{array}$ \\
\hline
\end{tabular}

B.8

Ma parole a influencé ma vie plus que tout autre chose
Fortement en
désaccord
En désaccord
Pas sûr(e)
En accord
Fortement en accord

Je ne me mets pas en colère lorsque je ne peux pas me faire comprendre

\begin{tabular}{|c|c|c|c|c|}
\hline $\begin{array}{l}\text { Fortement en } \\
\text { désaccord }\end{array}$ & En désaccord & Pas sûr(e) & En accord & $\begin{array}{l}\text { Fortement en } \\
\text { accord }\end{array}$ \\
\hline
\end{tabular}

B. 10

En dehors de ma parole, j'ai beaucoup d'autres qualités importantes

\begin{tabular}{|c|c|c|c|c|}
\hline $\begin{array}{l}\text { Fortement en } \\
\text { désaccord }\end{array}$ & En désaccord & Pas sûr(e) & En accord & $\begin{array}{l}\text { Fortement en } \\
\text { accord }\end{array}$ \\
\hline
\end{tabular}


Je suis conscient de la réaction des autres vis-à-vis de ma parole
Fortement en
désaccord
En désaccord
Pas sûr(e)
En accord
Fortement en accord

Ma famille n'est jamais ennuyée quand elle ne comprend pas ce que je dis
Fortement en
désaccord
En désaccord
Pas sûr(e)
En accord
Fortement en accord

Je n'accorde pas d'importance à ce que les gens pensent de ma parole

\begin{tabular}{|c|c|c|c|}
\hline $\begin{array}{l}\text { Fortement en } \\
\text { désaccord }\end{array}$ & En désaccord & Pas sûr(e) & $\begin{array}{l}\text { Fortement en } \\
\text { accord }\end{array}$ \\
\hline
\end{tabular}

Les autres me traitent comme si j'étais stupide parce qu'ils ne peuvent pas me comprendre

\begin{tabular}{|c|c|c|c|}
\hline $\begin{array}{l}\text { Fortement en } \\
\text { désaccord }\end{array}$ & En désaccord & Pas sûr(e) & En accord \\
\hline
\end{tabular}

Les gens ne sont pas gênés lorsque je n'arrive pas à me faire comprendre
Fortement en
En désaccord
Pas sûr(e)
En accord
Fortement en accord

Les inconnus ne me considèrent pas négativement parce que j'ai un problème de parole
Fortement en désaccord
En désaccord
Pas sûr(e)
En accord
Fortement en accord

Les gens sont généralement patients lorsque je parle lentement

\begin{tabular}{|c|c|c|c|}
\hline $\begin{array}{l}\text { Fortement en } \\
\text { désaccord }\end{array}$ & En désaccord & Pas sûr(e) & En accord \\
\hline
\end{tabular}

Mes amis font plus d'efforts pour me comprendre que ma famille

\begin{tabular}{|c|c|c|c|c|}
\hline $\begin{array}{l}\text { Fortement en } \\
\text { désaccord }\end{array}$ & En désaccord & Pas sûr(e) & En accord & $\begin{array}{l}\text { Fortement en } \\
\text { accord }\end{array}$ \\
\hline
\end{tabular}

Les personnes font semblant de me comprendre alors que je sais que ce n'est pas le cas
Fortement en
En désaccord
Pas sûr(e)
En accord
Fortement en accord

Les gens pensent parfois que j'ai bu alors que ce n'est pas le cas
Fortement en désaccord
En désaccord
Pas sûr(e)
En accord
Fortement en accord

La plupart des gens font un effort pour comprendre ce que je dis

\begin{tabular}{|c|c|c|c|}
\hline $\begin{array}{l}\text { Fortement en } \\
\text { désaccord }\end{array}$ & En désaccord & Pas sûr(e) & En accord \\
\hline
\end{tabular}

J'accorde de l'importance à l'opinion des autres à l'égard de ma parole
Fortement en
désaccord
En désaccord
Pas sûr(e)
En accord
Fortement en accord

C.13 Je n'ai jamais le sentiment que les autres rient ou se moquent de ma parole
Fortement en
désaccord
En désaccord
Pas sûr(e)
En accord
Fortement en accord

C.14

Maintenant, les personnes sont plus condescendantes à cause de ma parole
Fortement en
désaccord
En désaccord
Pas sûr(e)
En accord
Fortement en accord 
D.1 Malgré mes difficultés à parler, je n'évite pas de communiquer avec les gens que je connais
Fortement en
En désaccord
Pas sûr(e)
En accord
Fortement en accord

D.2

Ma vie sociale n'a pas changé à la suite à ma dysarthrie

$\begin{array}{clll}\begin{array}{c}\text { Fortement en } \\ \text { désaccord }\end{array} \text { En désaccord } & \text { Pas sûr(e) } & \text { Fortement en } \\ \text { accord }\end{array}$

D.3

Quand les gens ne me comprennent pas, j'essaye de faire passer mon message par d'autres moyens

\begin{tabular}{|c|c|c|c|c|}
\hline $\begin{array}{c}\text { Fortement en } \\
\text { désaccord }\end{array}$ & En désaccord & Pas sûr(e) & En accord & $\begin{array}{l}\text { Fortement en } \\
\text { accord }\end{array}$ \\
\hline
\end{tabular}

D.4

J'évite d'utiliser le téléphone à cause de ma parole

$\begin{array}{cccc}\begin{array}{c}\text { Fortement en } \\ \text { désaccord }\end{array} \quad \text { En désaccord } & \text { Pas sûr(e) } & \text { En accord } & \begin{array}{c}\text { Fortement en } \\ \text { accord }\end{array}\end{array}$

D.5

J'évite de demander des articles dans des magasins
Fortement en
désaccord
En désaccord
Pas sûr(e)
En accord
Fortement en accord

D.6

Je compte sur les autres pour parler à ma place à chaque fois que c'est possible
Fortement en désaccord
En désaccord
Pas sûr(e)
En accord
Fortement en accord

D.7

A cause de ma parole, j'écoute plus que je ne prends part aux conversations

\begin{tabular}{|c|c|c|c|c|}
\hline $\begin{array}{l}\text { Fortement en } \\
\text { désaccord }\end{array}$ & En désaccord & Pas sûr(e) & En accord & $\begin{array}{l}\text { Fortement en } \\
\text { accord }\end{array}$ \\
\hline
\end{tabular}

D.8

Je n'évite pas de parler à des inconnus

\begin{tabular}{|c|c|c|c|c|}
\hline $\begin{array}{l}\text { Fortement en } \\
\text { désaccord }\end{array}$ & En désaccord & Pas sûr(e) & En accord & $\begin{array}{l}\text { Fortement en } \\
\text { accord }\end{array}$ \\
\hline
\end{tabular}

D.9 Je me sens à l'aise pour m'exprimer dans la plupart des situations, tant à la maison qu'à l'extérieur
Fortement en
En désaccord
Pas sûr(e)
En accord
Fortement en désaccord

Mes difficultés de parole limitent ma vie sociale

D. 10

Fortement en désaccord

D.11

En désaccord Pas sûr(e)

J'évite de parler seulement lorsque je suis fatigué(e)

En désaccord

Pas sûr(e)

En accord
Fortement en accord

D.12

A cause de ma parole, je me suis isolé(e) socialement

\begin{tabular}{|c|c|c|c|c|}
\hline $\begin{array}{l}\text { Fortement en } \\
\text { désaccord }\end{array}$ & En désaccord & Pas sûr(e) & En accord & $\begin{array}{c}\text { Fortement en } \\
\text { accord }\end{array}$ \\
\hline
\end{tabular}


- Citer 4 préoccupations qui vous dérangent ou vous inquiètent, à l'exception de la parole ou de la communication :
A.
B.
C
Ajouter maintenant à cette liste votre problème spécifique de parole
E. Trouble de la parole

- Donner une priorité à ces difficultés de 1 à 5 , où 1 correspondra à votre plus grande préoccupation et 5 à celle qui vous inquiète le moins ; c'est-à-dire :

[1] - La plus préoccupante/ inquiétante
[2] - Très préoccupante/ inquiétante
[3] - Préoccupante/ inquiétante
[4] - Peu préoccupante/ inquiétante
[5] - La moins préoccupante/ inquiétante

\section{$\square$ Ce questionnaire a été rempli par (cocher une seul case) :}

Moi seul
Moi, avec l'aide d'un parent ou un ami 